d'immunodéficience acquise (SIDA). Le "Centre for Disease Control" à Atlanta définit SIDA comme "une maladie indiquant de façon probable la présence d'immuno-déficience cellulaire chez un sujet qui ne présente aucune des causes connues provoquant habituellement une telle affection".

Certains experts américains croient que SIDA est une maladie transmissible par le sang et ses dérivés. Ils ont recommandé l'élimination des groupes à risques élevếs des listes de donneurs. L'étiologie et l'épiclémiologie de SIDA demeurent imprécises et l'éteridue du problème n'est pas encore connue.

Les anesthésistes canadiens manipulent probablement plus de dérivés que tout autre groupe de médecins. L'utilisation intelligente et responsable de ces dérivés est essentielle pour maintenir des réserves suffisantes. Le docteur Blajchman et ses collaborateurs ont d'ailleurs mis l'accent sur ce point dans leur article.

A la façon malheureusement bien canadienne, nous avons tendance à ne pas apprécier la qualité et les exigences élevées de notre programme de sang qui fait pourtant l'envie de plusieurs nations. La Société canadienne de la Croix-Rouge, en collaboration avec la profession medicale, les gouvernements et autres groupes intéressés, lutte continuellement pour édifier et améliorer ce programme. Les anesthésistes peuvent faire leur part en se servant intelligemment des dérivés que la Croix-Rouge leur foumit.

\title{
Anticholinergic premedication for infants and children
}

The routine administration of anticholinergic drugs in premedication has been the subject of much debate during the past two decades, 1,2 and there is evidence that these drugs are less utilized than in former times. ${ }^{3}$ However, infants and children have been considered separately, and authorities who have advised against the routine use of anticholinergic in adults have been careful to exclude paediatric patients from their recommendations. Authors of textbooks of paediatric anaesthesia $a^{4,5}$ continue to advise that a vagal blocking agent is important in pacdiatric anaesthesia to prevent bradycardia due to mechanical stimulation, ${ }^{6}$ following succinylcholine," or accompanying halothane administration. ${ }^{8}$ The administration of atropine by the intravenous route has been considered to ensure the most certain vagal-blocking effect, and has been advised ${ }^{9}$ whenever powerful reflexes may be elicited, for example, the oculo-cardiac reflex during strabismus surgery.

D.J. Steward, Anaesthetist-in-Chief, Department of Anaesthesia, The Hospital for Sick Children, Toronto, Ontario MSG 1 X8.
In their paper in this issue, Blanc and his colleagues ${ }^{10}$ question the necessity for intravenous anticholinergic drugs prior to manipulation of the extraocular muscles of infants and children. Instead, they suggest that intramuscular atropine, well-managed anaesthesia with normocapnia and good oxygenation, together with gentle surgical manipulation of the extraocular muscles, may remove the need for intravenous anticholinergic drugs and "their potential risks." The authors stress the need for careful co-operation between surgeon and anaesthetist, careful monitoring of the heart rate, and immediate release of extraocular muscle traction if bradycardia occurs.

How dangerous is the oculo-cardiac reflex (OCR), and indeed, what are the potential risks of the intravenous use of anticholinergic drugs in paediatric patients? In the introduction to their paper, Blanc and his colleagues document the dangers of the OCR: episodes of cardiac arrest, ventricular fibrillation, and more than 60 deaths. Even if other causes may have contributed to some of these disasters, the description of the dangers is impressive. Intravenous anticholinergic drugs can 
effectively block the OCR. ${ }^{11}$ But with what risks of their own? The documentation of serious complications following atropine administered intravenously to children is less convincing. In arguing against the use of atropine to control the OCR, Schartz ${ }^{12}$ states that the arrhythmias in patients given atropine were of a more disturbing nature than the bradycardia which was prevented. He does not, however, document any serious outcome of these arrhythmias, which apparently resolved spontaneously. A search of the literature for accounts of any serious complications following atropine in normal doseage administered to healthy children produces nothing worrying; ${ }^{13}$ even colossal overdosage by the oral route is followed by complete recovery. Atropine is indeed a very safe drug. ${ }^{14}$ Many anaesthetists prefer to give atropine to children intravenously at the time of induction of anaesthesia. This spares the child an intramuscular injection and subsequent unpleasant dry mouth. Sedative premedicants, if indicated, can be given orally or rectally.

What then is the best advice for the practicing anaesthetist, as he cares for a healthy child during ophthalmic surgery? Many are not privileged to work with an ophthalmologist in the ideal close co-operation which is enjoyed by Dr. Blanc and his associates. He must choose the procedure which has been shown to be safest for his patient. There is evidence that serious complications may occasionally result from initiation of the oculo-cardiac reflex. Intravenous anticholinergics have been shown to effectively block the ocula-cardiac reflex. The evidence that these drugs cause serious complications in healthy children is missing. My conclusion must remain that the best advice is to administer intravenous atropine $0.02 \mathrm{mg} \cdot \mathrm{kg}^{-1}$ body weight to patients immediately prior to surgery involving the extraocular muscles; then to monitor the heart rate carefully during surgery.

Infants and children with congenital heart disease, and especially those with obstructive lesions (aortic stenosis, pulmonary stenosis) do deserve special consideration: They may not tolerate the tachycardia which results following intravenous atropine. However, it should be noted that, in younger infants the increase in heart rate is less than in older patients. ${ }^{15}$ Patients with congenital heart disease may benefit if the regime outlined by Blanc and his colleagues is very carefully followed.

\section{References}

1 Holt $A T$. Premedication with atropine should not be routine. Lancet $1962 ; 2: 984-5$.

2 Inglis JM, Barrow MEH. Premedication - a reassessment. Proc. Royal Society Med. 1965; 58: 29-32.

3 Mirakhur RK, Clarke RSI, Dundee JW, MCDonald $J R$. Anticholinergic drugs in anaesthesia - a survey of their present position. Anacsthesia 1978; 33 : 133-8.

4 Smith RM. Anaesthesia for infants and children. P. 98, C.V. Mosby, St. Louis, IV cd., 1980.

5 Brown TCK, Fisk GC. Anaesthesia for children. P. 107, Blackwell, Oxford, 1st ed., 1979.

6 Sagarminaga J. Wynands JE. Atropine and the electrical activity of the heart during induction of anaesthesia in children. Can Anacsth Soc J, 1963; 10: $328-42$.

7 Leigh MD, McCoy DD, Belton $M K$, Lewis GB. Bradycardia following intravenous administration of succinylcholine chloride to infants and children. Anesthesiology 1957; 18: 698-702.

8 Barash PG, Glanz S, Katz JD et al. Ventricular function in children during halothane anesthesia: an echocardiographic evaluation. Anesthesiology 1978; 49: 79-85.

9 Meyers EF, Tomeldan SA. Glycopyrrolate compared with atropine in prevention of the oculocardiac reflex during eye muscle surgery. Anesthesiology 1979; 51 : 350-2.

10 Blanc VF, Hardy JF, Milot J, Jacob JL. The oculo-cardiac reflex: a graphic and statistical analysis in infants and children. Can Anaesth Soc J 1983; 30: 360 (This issue).

11 Shutt $L E$, Bowes JB. Atropine and hyoscine. Anaesthesia 1979; 34: 476-90.

12 Schwartz $H$. Oculocardiac reflex: is prophylaxis necessary? In Mark L.C. and Ngai, S.H. Eds: Highlights of clinical anesthesiology, pp. 111-4, Harper and Row, New York, 1971.

13 Mackenzie AL, Pigou JFG. Atropine overdose in three children. Br J Anaesth. 1971; 43: 1088-90.

14 Arthurs GJ, Davies $R$. Atropine - a safe drug. Anaesthesia 1980; 35: 1077-9.

15 Dauchot $P$, Gravenstein JS. Effects of atropine on the electrocardiogram in different age groups. Clin Pharmacol Ther, 1971; 12: 274-80. 